\title{
Waste-Energy (Heat) Recovery System from the Gases Compressed by an Oil-Free Screw Compressor
}

\author{
Iulian Vlăducă ${ }^{1, *}$, Ramona Stanciuc ${ }^{1}$, Răzvan Bimbaşa ${ }^{1}$ and Sorin Gabriel Tomescu ${ }^{1}$ \\ ${ }^{1}$ INCDT COMOTI, Bucharest, Romania
}

\begin{abstract}
During compression, a gas heats up, almost in all cases this heat being wasted, either by cooling the gas because it is too hot for the application, or by storing the gas and letting the compressed gas cool naturally in the storage tank. This paper presents a waste-energy (heat) recovery system from the gases compressed by an oil-free screw compressor. The gases compressed by this compressor have a very high temperature compared to an oil injected screw compressor, due to the fact that the oil used to lubricate the rotors also acts as a heat sink, the oil free variant which is used when you want a very high purity of the gas, has higher tolerances and more friction between the rotors which result in a higher gas temperature. The recovery system uses a heat exchanger to extract the waste energy from the gas and at the same time it will cool it for immediate use. Depending on the requirements, the energy recovered may be used immediately to produce useful work or stored for a later use. It may be used for heating a building, to produce steam for a turbine driving electrical generator, or in other forms.
\end{abstract}

\section{Introduction}

A method for rational use of energy in air compression is heat recovery, which is a secondary product in the compressed air production. Thus, the primary energy is directly transformed into compressed air, and indirectly into heat, which can be used in central heating systems. There is a great potential of energy that can be saved or recovered from compressed air systems, also having great potential for improving both the energy savings and $\mathrm{CO}_{2}$ emissions $[1]$.

Companies have developed their own heat recovery systems in self-contained complete systems, rotary screw compressors, boosters and blowers that are particularly well suited for heat recovery. The compressor's exhaust heat can be used as hot air for spaces or process heating purposes. For example, by the direct use of the recyclable heat via an exhaust air ducting system, up to $96 \%$ can be used, or by using a warm cooling medium that can heat water up to $70^{\circ} \mathrm{C}$ via a heat exchanger, up to $76 \%$ of heat energy can be recovered [2].

In a compressed air energy storage (CAES) system, proposed, the compressed air is stored in a pressurised tank, and the air is than released in an expander turbine to generate electricity.

\footnotetext{
* Corresponding author: iulian.vladuca@comoti.ro
} 
The disadvantage is that when the compressed air is released, it cools, reducing the amount of available energy.

The key element for improving the efficiency is to develop a high temperature air storage system. The energy conversion process can be adiabatic or diabatic (nearly isothermal), and also in other thermodynamic cycle configurations. In a diabatic system, additional heating of the expanded air is required to generate additional output energy. In a adiabatic system, the compression heat is stored at a higher temperature in the storage tank and hence a generation of a larger quantity of energy output can be expected [3].

\section{Heat recovery system design}

The fundamental research of new gas compression solutions has led to innovative solutions in the development of oil-free helical compressors. The TURBO 2020 Core Program, carried out with the support of MCI, conducts a fundamental research in line with the general objectives of the INCDT COMOTI on the development of oil-free rotary machines based on the knowledge developed on oil-injected screw compressors. For this purpose, was purchased as a study material, an oil-free compression unit type CD14D1 [4, 5] from GHH RAND, Germany (Figure 1).

a.

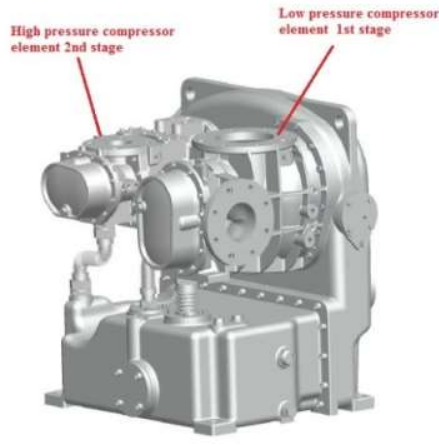

b.

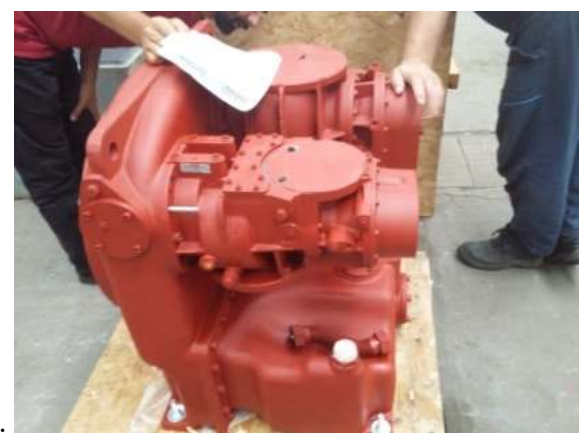

Fig. 1. a. Oil-free compression unit type CD14D1 [1, 2]; b. the purchased unit from GHH-Rand

The following table shows the different compressor stages and their application in the respective compressor blocks [4]:

Table 1. Assignment of compressor stages to compressor blocks.

\begin{tabular}{|c|c|c|c|c|}
\hline \multicolumn{2}{|c|}{ Type } & Single-stage blocks & Double-stage blocks & Booster \\
\hline \multirow{6}{*}{ 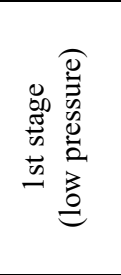 } & CDA80 & - & CD8D & - \\
\hline & CDA82 & CD9S & CD14D1 & - \\
\hline & CDA96 & $\mathrm{CD} 14 \mathrm{~S}$ & CD14D1 & - \\
\hline & CDA128 & $\begin{array}{l}\text { CD23S } \\
\text { CD26S }\end{array}$ & CD26D & - \\
\hline & CDA160 & CD42S & CD42D1 & - \\
\hline & CDA208 & CD72S1 & - & - \\
\hline \multirow{4}{*}{ 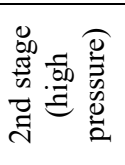 } & CDB54 & - & CD8D & CD8HD \\
\hline & CDB68 & - & CD14D1 & CD14HD1 \\
\hline & CDB90 & - & CD26D & CD26HD \\
\hline & CDB114 & - & CD42D1 & - \\
\hline
\end{tabular}

The cells with bolded frame in the left in Table 1 are the units composing the double stage CD14D1 compressor. In Table 2 are the nominal parameters of the compressor stages. In the paper the values from the columns with normal frame were used. 
Table 2. Nominal limitations of using CD-D without CD8D (according to clearance classes).

\begin{tabular}{|c|c|c|c|c|}
\hline \multirow{2}{*}{ Parameter } & \multicolumn{2}{|c|}{ 1st stage } & \multicolumn{2}{c|}{ 2nd stage } \\
\cline { 2 - 5 } & close & open & close & open \\
\hline Maximum suction temperature $\left[{ }^{\circ} \mathrm{C}\right]$ & 46 & 50 & 51 & 60 \\
\hline Maximum discharge temperature $\left[{ }^{\circ} \mathrm{C}\right]$ & 227 & 250 & 227 & 270 \\
\hline Maximum discharge pressure $[$ bar absolute] & 3.96 & 4.17 & 8.63 & 12.7 \\
\hline
\end{tabular}

From the technological diagram shown in the figure 2, we have:

First stage of compression with CDA96 compressor unit, which gives compressed air at 4.17 bar (abs) and $250^{\circ} \mathrm{C}$, and second stage of compression with CDB68 compressor unit, that give compressed air at 12.7 bar (abs) and $270^{\circ} \mathrm{C}$ (see tables 1 and 2 from above). The flow of the compressor at maximum load is $M_{\text {air }}=1330 \mathrm{~m}^{3} / \mathrm{h}=0.436 \mathrm{~kg} / \mathrm{s}$, at $20^{\circ} \mathrm{C}$ and at an air humidity of $60 \%$, see also figure 3, the output data done with T1996WIN, Vers. 2.2.22, GHH Rand software.

In the technological diagram, figure 2, are represented the coolers for that two stages of compression in the situation of a beneficiary request for 12 bar (abs) compressed air at $60^{\circ} \mathrm{C}$.

The amount of the lost heat rejected and the consumption of energy is significant. The quantity of the rejected energy in the first and second stages is given by the equation:

$$
Q_{\text {air }, \text { comp }}=M_{\text {air }} \cdot c_{p, \text { air }} \cdot\left(T_{2}-T_{1}\right)
$$

We have the following amount of heat lost for the two compression stages:

$$
\begin{gathered}
Q_{\text {air,comp }, 1 s t}=M_{\text {air }} \cdot c_{p, \text { air }} \cdot\left(T_{2,1 s t}-T_{1,1 s t}\right) \cong 88 \mathrm{~kW} \\
Q_{\text {air,comp }, 2 n d}=M_{\text {air }} \cdot c_{p, \text { air }} \cdot\left(T_{2,2 n d}-T_{1,2 n d}\right) \cong 92.4 \mathrm{~kW} \\
Q_{\text {air,comp }, 1 s t+2 n d}=Q_{\text {air,comp }, 1 s t}+Q_{\text {air,comp }, 2 n d} \cong 180.4 \mathrm{~kW}
\end{gathered}
$$

Converting in $\mathrm{kcal} / \mathrm{h}$ and $\mathrm{Btu} / \mathrm{h}$, we have:

$$
Q_{\text {air,comp }, 1 s t+2 n d}=155116 \mathrm{kcal} / \mathrm{h}, \text { or } 615550 \mathrm{Btu} / \mathrm{h}
$$

For an air to air cooler driven by an electrical motor at $1500 \mathrm{rpm}$, with a dimension of the cooler $=1200 \mathrm{~mm}$ (tube length) $\times 1500 \mathrm{~mm} \times 140 \mathrm{~mm}$, the total electrical power lost for the cooling the air of two compressor stages is $E_{\text {lost }}=11 \mathrm{~kW}$.

If we compare with the energy consumed by the main electrical motor driving the compressor unit that is about is $E_{\text {consumption }}=173 \mathrm{~kW}$ (calculations done with T1996WIN, Vers. 2.2.22, GHH Rand software, see figure 3, the output data), the lost energy used for cooling the air represent about:

$$
\eta_{\text {lost }}=\frac{E_{\text {lost }}}{E_{\text {consumption }}} \cdot 100=6.35 \%
$$




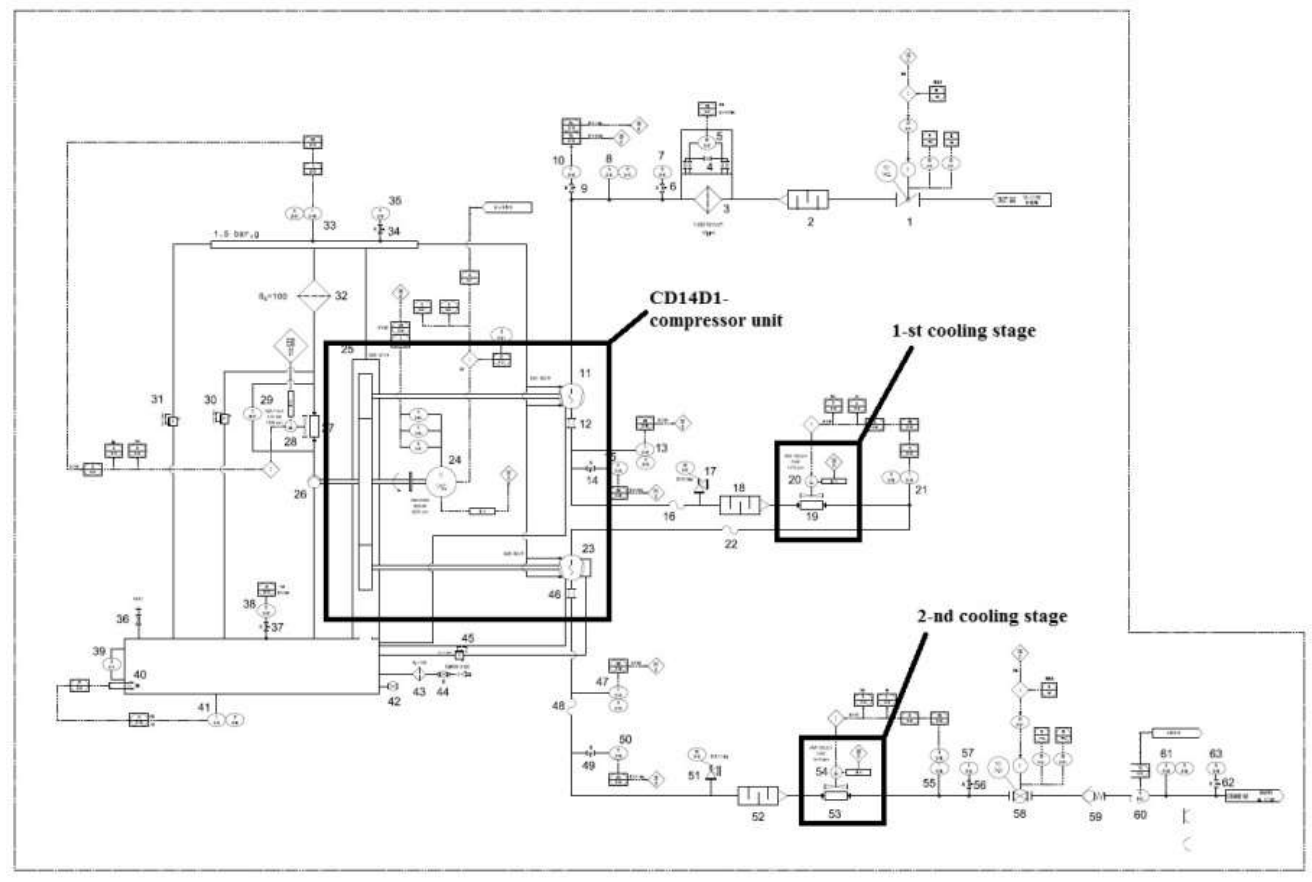

Fig. 2. The technological diagram for double oil-free compressor with CD14D1 unit

\begin{tabular}{|c|c|c|c|c|}
\hline \multicolumn{3}{|c|}{$\begin{array}{l}\text { GHH RAND Schraubenkompressoren GmbH } \\
\text { Design program for oil1-free } \\
\text { screw Compressors }\end{array}$} & \multicolumn{2}{|c|}{$\begin{array}{l:c}\text { PAGE } & 2 / \\
\text { DATE } & 03.04 .2019 \\
\text { S/N } & : 0300 / 2 / 0\end{array}$} \\
\hline $\begin{array}{ll}\text { CODEWORD } & \vdots \\
\text { JOB-/PROJECT-NO. } & \begin{array}{l}\text { Double Stage } \\
\text { LOIAL }\end{array}\end{array}$ & & $\begin{array}{l}\text { PREPARED: } \\
\text { CHECKED : }\end{array}$ & Iulian vlad & duca \\
\hline \multicolumn{5}{|l|}{, } \\
\hline $\begin{array}{l}\text { AMBIENT DATA } \\
\text { Ambient air pressure abs. } \\
\text { Ambient temperature } \\
\text { Rel. humidity }\end{array}$ & $\begin{array}{l}\text { bar } \\
\text { "cc } \\
\%\end{array}$ & $\begin{array}{l}1.000 \\
20.0 \\
60.0\end{array}$ & $\begin{array}{l}14.50 \\
68.0\end{array}$ & $\underset{F}{p s i a}$ \\
\hline $\begin{array}{l}\text { SET DATA } \\
\text { Compressor type / Gear set / i } \\
\text { Motor speed } \\
\text { Minimum speed for proper lubrication } \\
\text { Medium to be compressed }\end{array}$ & \multicolumn{4}{|c|}{ in $\begin{array}{l}\mathrm{CD} 14 \mathrm{D} / 14 / 3.667 \\
2975 \\
\text { in } 2456 \\
\text { Air }\end{array}$} \\
\hline $\begin{array}{l}\text { Suction pressure abs. } \\
\text { suction temperature } \\
\text { Re1. humidity } \\
\text { Discharge pressure abs. } \\
\text { Discharge temperature } \\
\text { Re1. humidity } \\
\text { Intercooling to }\end{array}$ & 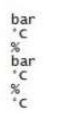 & $\begin{array}{l}1.000 \\
20.0 \\
60.0 \\
11.600 \\
50.0 \\
100.0 \\
50.0\end{array}$ & $\begin{array}{l}14.50 \\
68.0 \\
168.24 \\
122.0 \\
122.0\end{array}$ & $\begin{array}{l}\underset{F}{p s i a l} \\
p \underset{F}{p s i a} \\
\cdot F\end{array}$ \\
\hline $\begin{array}{l}\text { volume flow (related to suct. cond.) } \\
\text { Mass flow (wet) } \\
\text { Mass flow (dry) } \\
\text { volume flow (rel. to std.temp. \& pr.) } \\
\text { volume flow reflated to } 30 " \text { Ha. } 60 \text {. } 30\end{array}$ & $\begin{array}{l}\mathrm{m} / \mathrm{h} \\
\mathrm{kg} / \mathrm{h} \\
\mathrm{kg} / \mathrm{h} \\
\mathrm{m} 3 / \mathrm{h} \\
\mathrm{m3} / \mathrm{h}\end{array}$ & $\begin{array}{r}1329.6 \\
1571.8 \\
1558.0 \\
1205.5 \\
1270.8 \\
173.2\end{array}$ & $\begin{array}{r}782.6 \\
57.76 \\
57.25 \\
709.5 \\
748.0 \\
232.2\end{array}$ & $\begin{array}{l}\mathrm{cfm} \\
\mathrm{lbs} / \mathrm{min} \\
\mathrm{lbs} / \mathrm{min} \\
\mathrm{cfm} \\
\mathrm{cfm} \\
\mathrm{sfm}\end{array}$ \\
\hline $\begin{array}{l}\text { Thermal output oilcooler ) } \\
\text { condensating water in intercooler } \\
\text { Thermal output intercooler } \\
\text { condensating water in after cooler } \\
\text { Thermal output aftercooler } \\
\text { Pressure loss before block } \\
\text { Pressure loss between LP- and HP-stage } \\
\text { Pressure loss after block }\end{array}$ & $\begin{array}{l}\mathrm{kw} \\
\mathrm{kg} / \mathrm{h} \\
\mathrm{kW} \\
\mathrm{kg} / \mathrm{h} \\
\mathrm{kw} \\
\mathrm{bar} \\
\mathrm{bar} \\
\mathrm{bar}\end{array}$ & $\begin{aligned} 15.9 \\
0.0 \\
55.0 \\
3.4 \\
85.6 \\
0.020 \\
0.200 \\
0.200\end{aligned}$ & $\begin{array}{c}15.1 \\
0.00 \\
52.1 \\
0.12 \\
81.2 \\
0.29 \\
2.90 \\
2.90\end{array}$ & $\begin{array}{l}\mathrm{BTU} / \mathrm{s} \\
1 \mathrm{bs} / \mathrm{min} \\
\mathrm{BTU} / \mathrm{s} \\
1 \mathrm{bs} / \mathrm{min} \\
\mathrm{BTU} / \mathrm{s} \\
\mathrm{psi} \\
\mathrm{psi} \\
\mathrm{psi}\end{array}$ \\
\hline $\begin{array}{l}\text { orlpump } \\
\text { volume flow oilpump } \\
\text { Shaft power oilpump }\end{array}$ & $\mathrm{kW} / \mathrm{min}$ & $\begin{array}{l}R 25 / 20 F \\
55.5 \\
0.83\end{array}$ & $\begin{array}{l}-M 6-50 \\
14.7 \\
1.11\end{array}$ & $\underset{\mathrm{HP}}{\mathrm{gpm}}$ \\
\hline $\begin{array}{l}\text { oil viscosity group } \\
\text { oil volume flow to compressor )* } \\
\text { oil inlet temperature } \\
\text { Temperature oil out (mean value) )* }\end{array}$ & $\begin{array}{l}\mathrm{cst} \\
\mathrm{L} / \mathrm{min} \\
\mathrm{c} \\
\mathrm{c}\end{array}$ & $\begin{array}{l}46 \\
40.6 \\
50.0 \\
62.9\end{array}$ & $\begin{array}{r}10.7 \\
122.0 \\
145.3\end{array}$ & $\underset{F}{g p m}$ \\
\hline $\begin{array}{l}\text { Jacket cooling included } \\
\text { Medium jacket cooling }\end{array}$ & owe & ar cons & sump & on \\
\hline $\begin{array}{l}\text { STAGE DATA } \\
\text { Male rotor speed } \\
\text { Male rotor tip speed } \\
\text { suction pressure abs. } \\
\text { Suction temperature } \\
\text { Re1. humidity } \\
\text { Discharge presure abs. } \\
\text { Discharge temperature }\end{array}$ & $\begin{array}{l}1 / \mathrm{min} \\
\mathrm{m} / \mathrm{s} \\
\text { bar } \\
\dot{c}^{\mathrm{c}} \\
\gamma^{\mathrm{b}} \\
\text { bar } \\
\text { car }\end{array}$ & $\begin{array}{c}\text { CDA96 } \\
10908 \\
82.9 \\
0.980 \\
20.0 \\
58.8 \\
3.437 \\
172.8\end{array}$ & $\begin{array}{l}\text { CDB68w } \\
17999.7 \\
81.7 \\
3.237 \\
50.0 \\
36.8 \\
11.800 \\
238.6\end{array}$ & \\
\hline $\begin{array}{l}\text { Volume flow (rel. to stage suct. con. } \\
\text { Shaft power stage }\end{array}$ & $\underset{\mathrm{kW}}{\mathrm{m} 3 / \mathrm{h}}$ & $\begin{array}{r}1374.4 \\
77.6\end{array}$ & $\begin{array}{r}452.8 \\
94.8\end{array}$ & \\
\hline
\end{tabular}

Fig. 3. Power consumption for double oil-free compressor with CD14D1 unit, output data 
In the proposed work the energy lost in cooling the air for the two stages compressor, is used in a CAES system [6, 7]. CAES system uses energy at the tip of electricity production to compress the air in pressure vessels or in depleted gas fields or in depleted or preserved salt mines. The compressor and heat exchangers are closed positioned. The compressor is driven by an electric motor and the expander drives an electric generator. After compression, the air is introduced into pressure vessels or deposits, depending on the amount of energy needed to be injected later into the grid, see figure 4 . It is supposing that the compressor will work about 4 hours in a day, and the expander will work about 1 hour in the maximum grid load. That mean the storage air will be available about 20 hours/day. At a gradient of losing temperature about $1{ }^{\circ} \mathrm{C} / \mathrm{h}$, it is supposed that the tank temperature after 20 hours to be less with $20^{\circ} \mathrm{C}$, in the best insulation.

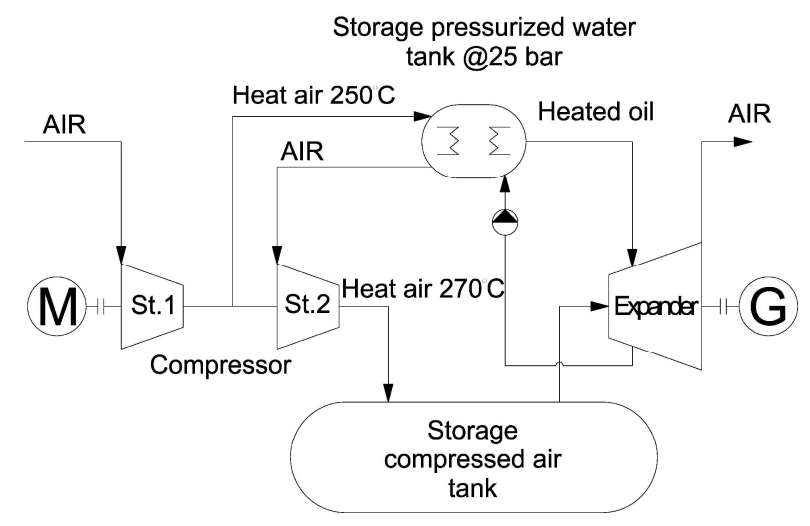

Fig. 4. The proposed recovery of heat with a CAES system

INCDT COMOTI has developed a piece of equipment for converting the energy of compressed gas into green electricity. This unique group operates using oil injection screw compressor. The thermodynamic cycle of an injection screw compressor that is a volumetric machine with positive displacement is also studied in the present $[8,10]$ and is used in refrigeration and air conditioning, but also in power generation. COMOTI's Expander Helical-Generator is an expander in oil-injected turbine configuration (advantageous solution for relatively small flows) that has the advantages: high efficiency due to near-isothermal compression, low maintenance costs due to its very good reliability, few pieces in motion [8, 9]. In this case, COMOTI developed the $37 \mathrm{~kW}$ screw oil injected expander from a GHH screw compressor in collaboration with GHH -Rand company, see figure 5 [10].

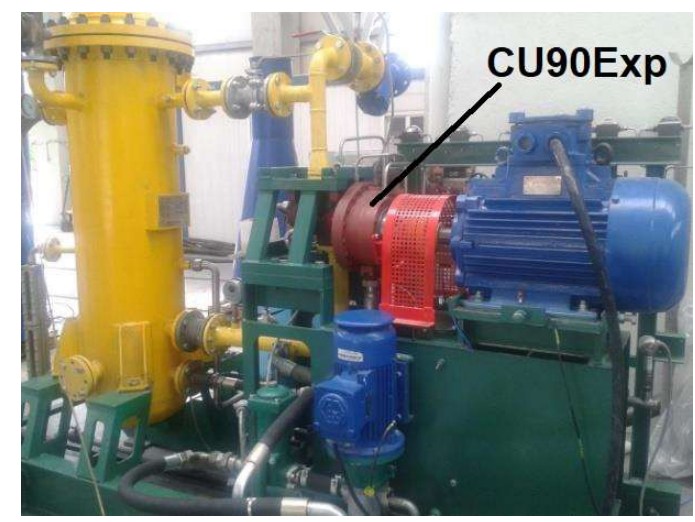

Fig. 5. The $37 \mathrm{~kW}$ screw oil injected expander [11] 


\section{Mathematical computation of expansion power}

The process of producing mechanical energy in the turbine through irreversible adiabatic expansion of natural gas is accompanied by a decrease in temperature. Since is imposed a minimum gas temperature at the exit pipe of the expander, about $5^{\circ} \mathrm{C}$, it results that the gas must be preheated before entering in the helical turbine. In our case, because the screw oil injection turbine, the oil will be heated by the first stage of the oil-free compressor, and that will cause the heating of the inlet compressed air in the turbine, in the case of lower temperatures of the compressed air, see figure 4 from above.

The expander is working with 10 bar (abs) suction pressure, because the maximum pressure of the tank is 12 bar (abs), at an air flow:

$$
M_{\text {air } \exp }=500 \mathrm{~m}^{3} / \mathrm{h}=0.179 \mathrm{~kg} / \mathrm{s} \quad\left(\text { at } 20^{\circ} \mathrm{C} \text { and } 60 \%\right. \text { relative humidity) }
$$

In the equations will be used the mass flow rate in $[\mathrm{kg} / \mathrm{s}]$.

In [7], the inlet pressure is the maximum allowed, but is not the working pressure. If we keep the same expansion ratio, with $p_{\text {in }}=21$ bar (abs) and $P_{\text {out }}=4.5$ bar (abs), we have:

$$
\pi_{\text {exp }}=\frac{p_{\text {in }(a b s)}}{p_{\text {out }}(a b s)}=4.67
$$

The output pressure $p_{\text {out }}$, for an input pressure $p_{\text {in }}$ of 10 bar (abs), will be:

$$
p_{\text {out }}=\frac{p_{\text {in }}}{\pi_{\text {exp }}}=2.14 \text { bar }(a b s)
$$

Working with a normal oil injected compressor, it is supposed that the exit temperature from the compressor to be around $90^{\circ} \mathrm{C}$. Because the storage compressed air tank is losing the temperature with about $1^{\circ} \mathrm{C} / \mathrm{h}, T_{\text {in }}$ in the expander after 20 hours will be about $70^{\circ} \mathrm{C}$. The total work of the expander is given by the equation:

$$
L_{\text {exp }}=c_{p} \cdot T_{\text {asp }} \cdot\left[\left(\pi_{\text {exp }}\right)^{\frac{k-1}{k}}-1\right]=191616.7 \mathrm{~J} / \mathrm{kg}
$$

Thus, the isentropic power of the expander will be:

$$
P_{\text {exp }, i s}=L_{\text {exp }} \cdot \frac{M_{\text {air }, \text { exp }}}{1000}=34.3 \mathrm{~kW}
$$

Working with an oil-free compressor, it is supposed that the exit temperature from the compressor to be around $270^{\circ} \mathrm{C}$, and with a loss of $20^{\circ} \mathrm{C}$, this will be $250^{\circ} \mathrm{C}$, and thus we will have:

$$
\begin{gathered}
L_{\text {exp }}=c_{p} \cdot T_{\text {asp }} \cdot\left[\left(\pi_{\text {exp }}\right)^{\frac{k-1}{k}}-1\right]=29212.7 \mathrm{~J} / \mathrm{kg} \\
P_{\text {exp }, \text { is }}=L_{\text {exp }} \cdot \frac{M_{\text {air }, \text { exp }}}{1000}=52.3 \mathrm{~kW}
\end{gathered}
$$

It is observed that in the case of using a free oil compressor, the power of the installation is increasing with about $52.5 \%$.

If we compare the increase in the electrical energy with about $18 \mathrm{~kW}$, we see that the energy lost with cooling the air is about $11 \mathrm{~kW}$ from the equation (6), and we have an increase with $7 \mathrm{~kW}$. We did not take into consideration the efficiency of power generator and other losses in the circuit. 
In real cases, the temperature at the inlet of the expander is not above $135^{\circ} \mathrm{C}$. In this case, the work and power calculated with the equations above are:

$$
L_{\text {exp }}=227913.0 \mathrm{~J} / \mathrm{kg} \text { and } P_{\text {exp }, \text { is }}=40.8 \mathrm{~kW}
$$

The power of the installation will increase just about $19 \%$, but the benefits of using the oil-free compressors is given by the possibility to have a bigger gradient of temperature loss in the air compressed tank, and in a longer storage time. The time increase in the case of $1^{\circ} \mathrm{C}$ gradient from 20 hours to about $270-70=200$ hours ( $\cong 8$ days), for the same power given at $70^{\circ} \mathrm{C}$, and make more attractive the idea of storage compressed air at high temperature, instead the reheating of it.

\section{Conclusions}

The major parameters in the analysis were storage pressure, air temperature and air mass flow, the mechanical work and available power of a small scale of maximum $40 \mathrm{~kW}$ CAES system with an oil free compressor. Few large CAES worldwide systems are known. Studies made on CAES systems, analyse different models at small scales, up to $1 \mathrm{~kW}$ discharge energy and at 12 bar storage pressures [12].

INCDT COMOTI has developed a piece of equipment for converting the energy of compressed air into green electricity, using an oil injected screw compressor and an oil injected screw expander. Studies have also been made regarding a free-oil screw compressor with the characteristics described in the present work. Future research will consider replacing the oil injected screw compressor with free-oil screw compressor to develop the technology for adiabatic-CAES systems with storage of the excess heat created during compression, and reuse of it for reheating.

It is estimated that this technology will become available at large scale and also at decentralised small scale in the near-future [13], where the use of free oil compressors at high pressure is an opportunity for further research and developing studies. Future research will thus focus on improving the free oil compressor systems and also the adiabatic storage tanks, for increasing the power and efficiency of the CAES systems.

The research work presented herein was funded by the Romanian National Research Program. This work was done through the TURBOPROP 2019-2020 Program, run with the support of Ministry of Research and Innovation.

\section{References}

1. https://www.researchgate.net/publication/329378770 The study on the heat recover y_from_air_compressors

2. https://www.kaeser.com/int-en/products/rotary-screw-compressors/heat-recovery/

3. https://www.researchgate.net/publication/326129759 Harnessing_Free_Energy From Nature For_Efficient_Operation_of_Compressed_Air_Energy_Storage_System and Unlocking the Potential_of_Renewable_Power_Generation

4. GHH Rand Installation manual for CD stages and CD blocks 23152176A - March, 2009

5. Compressed Air Energy Storage (CAES) | Energy Storage Association

6. https://www.researchgate.net/publication/300495902_Compressed_Air_Energy_Storag e

7. I. Mălăel, M. Sima, TURBO 2, 24 (2017) 
8. V. Petrescu, N. Toma, C. Slujitoru, TURBO 2, 31 (2017)

9. http://www.comoti.ro/docs/jurnal/Journal\%20TURBO_Vol\%20IV_No\%202_2017.pdf

10. COMOTI - Romanian Research and Development Institute for Gas Turbines

11. http://www.anre.ro/download.php?f=fqt $\% 2 \mathrm{BhQ} \% 3 \mathrm{D} \% 3 \mathrm{D} \& \mathrm{t}=$ wOutwdHbn $8 \% 2 \mathrm{BcmLP}$ fvrrV5ps\%3D

12. https://www.nature.com/articles/s41598-018-28025-5

13. http://ease-storage.eu/wp-

content/uploads/2016/07/EASE TD Mechanical_DCAES.pdf 